\title{
The Modern Lanham Act and the Death of
}

\section{Common Sense ${ }^{*}$}

\author{
Mark A. Lemley ${ }^{\dagger}$
}

[W] hat appear to be private disputes among hucksters almost invariably touch the public welfare. We shall therefore be concerned to ask, when courts protect trade symbols, whether their decisions further public as well as private goals. ${ }^{1}$

When Ralph Brown wrote his seminal article on trademark law fifty years ago, the modern era of trademark law had just begun. The Lanham Act, the foundation of trademark law today, was only two years old, ${ }^{2}$ and the nature of modern commerce was only just beginning to take shape.

Quite a lot has changed in fifty years. More and more of the currency of commerce is not goods, but information and even brand-loyalty itself. The economics of trademarks and advertising has grown increasingly sophisticated over this period. Most economists today view trademarks as valuable aids to efficient markets. Contemporaneous with this economic development, there has been a gradual but fundamental shift in trademark law. Commentators and even courts increasingly talk about trademarks ${ }^{3}$ as

* Copyright 1999, Mark A. Lemley and The Yale Law Journal.

$\dagger$ Professor of Law, University of Texas School of Law; Of Counsel, Fish \& Richardson, P.C., Austin, Texas. I would like to thank John Allison, Julie Cohen, Tom Cotter, Robert Denicola, Wendy Gordon, Rose Hagan, Paul Heald, Jessica Litman, Glynn Lunney, Tom McCarthy, David McGowan, Maureen O'Rourke, Malla Pollack, participants in a faculty colloquium at the University of Minnesota School of Law, and the editors of The Yale Law Journal for comments on an earlier draft.

I met Ralph Brown only once before his death, so I cannot reminisce about my friendship with him. But he has taught me a great deal through his writings, and I think the best possible tribute I could pay is to fight for a vision of the public interest of which I think he would approve. Cf. Robert Denicola, Freedom To Copy, 108 YALE L.J. 1661, 1661 (1999) ("Ralph devoted much of his career to holding the center. He worried that intellectual property law had begun to lean too far toward private rights at the expense of the public interest ....").

1. Ralph S. Brown, Jr., Advertising and the Public Interest: Legal Protection of Trade Symbols, 57 YALE L.J. 1165, 1167 (1948), reprinted in 108 YALE L.J. 1619, 1621 (1999).

2. Act of July 5, 1946, ch. 540,60 Stat. 427 (1946) (codified as amended at 15 U.S.C. $\$ \$ 1051-1127$ (1994)). The Lanham Act is the federal trademark statute.

3. While, strictly speaking, some of the developments I will discuss involve service marks, trade names, trade dress, or product configurations, rather than "trademarks" per se, I will use the term "trademark" in a broad sense to encompass all the symbols and indicia protected by the Lanham Act. 
property rights; as things valuable in and of themselves, rather than for the product goodwill they embody. Courts protect trademark owners against uses that would not have been infringements even a few years ago and protect as trademarks things that would not have received such protection in the past. And they are well on their way to divorcing trademarks entirely from the goods they are supposed to represent.

Unfortunately, the changes in trademark doctrine over the last fifty years are not supported by the new economic learning. Rather, these changes have loosed trademark law from its traditional economic moorings and have offered little of substance to replace them.

Brown's doctrinal approach offers a healthy dose of common sense in thinking about trademark law. While some of his observations about the economics of advertising should be read in light of more recent economic work, his philosophical and doctrinal observations about trademark doctrine and its fit with economic theory are worth reconsidering in light of the trends in trademark doctrine. In Part I of this Essay, I provide a brief sketch of the economic foundations of trademark law, considering both Brown's article and some of the new learning on the economics of advertising. I argue that the new economic learning, while useful, does not fundamentally change the nature of trademarks. In Part II, I argue that recent developments threaten to stretch the rationale of trademark law beyond all limits, and in Part II, I offer some preliminary thoughts on how we might restore common sense to the Lanham Act. Though space constraints prevent a full exposition of these ideas, I will offer some general ways in which courts and commentators might better align the goals and outcomes of trademark law.

\section{RALPH BROWN AND THE ECONOMICS OF ADVERTISING}

Brown's approach to trademark doctrine is to determine the goals of trademark law and then to determine how well the doctrine comports with these goals. For Brown, the goals of trademark law are bound up with the "informative function" of trademarks. Trademarks are a compact and efficient means of communicating information to consumers. By granting ownership rights over trademarks, we serve the twin goals of encouraging investment in product quality and preventing consumer deception. ${ }^{4}$ Brown quotes Learned Hand's useful admonition that "[w]e are nearly sure to go astray in [trademark law] as soon as we lose sight of the underlying principle that the wrong involved is diverting trade from the first user by

4. See Brown, supra note 1 , at 1185-87. 
misleading customers who mean to deal with him."5 For Brown, the wisdom of trademark doctrine can be measured by how well it hews to that purpose.

In particular, Brown was at pains to reject arguments that the law should protect trademarks either because of the perceived unfairness of competition by others, ${ }^{6}$ or as property in and of themselves. ${ }^{7} \mathrm{He}$ also expressed great concern with what he saw as the risks advertising posed for competition, in particular its capacity for artificial brand differentiation and a consequent stifling of competition even in largely homogenous product markets. ${ }^{8} \mathrm{He}$ was particularly concerned about advertising that sought to persuade rather than to inform. He described the theoretical case for the benefits of advertising as dubious and the empirical case as nonexistent. ${ }^{9}$ Brown was by no means alone in raising these challenges; opposition to advertising was perhaps a product of the times. ${ }^{10}$

The field of economics has responded well to some of Brown's challenges. In particular, while economists have by no means reached a consensus regarding the economic function of trademarks, they have offered considerable empirical evidence-both positive and negativeregarding the actual effects of trademarks and advertising. ${ }^{11}$ Whatever the empirical case, economists have offered at least three positive justifications for both trademarks and advertising.

5. S.C. Johnson \& Son v. Johnson, 116 F.2d 427, 429 (2d Cir. 1940), quoted in Brown, supra note 1, at 1184. For an argument that raises similar concerns, see Felix Cohen, Transcendental Nonsense and the Functional Approach, 35 CoLUM. L. REv. 809, 814-17 (1935).

6. See Brown, supra note 1, at 1199-1205.

7. While the property rationale for trademark law had been articulated the year before, see Rudolf Callmann, Unfair Competition Without Competition? The Importance of the Property Concept in the Law of Trade-Marks, 95 U. PA. L. REv. 443 (1947), it was not yet a serious part of trademark discourse. Nonetheless, Brown's resistance to the idea of trademarks as property in and of themselves can be seen in his discussion of dilution and in his repeated disdain for the "persuasive function of trade symbols." See Brown, supra note 1, at 1190, 1191-94.

8. See Brown, supra note 1 , at 1170-75.

9. See id. at 1178 .

10. Among the many arguments against the evils of advertising roughly contemporaneous with Brown's are JOE S. BAIN, INDUSTRIAL ORGANIZATION 255-56 (1968); EDWARD CHAMBERLAIN, THE THEORY OF MONOPOLISTIC COMPETITION 246-50, app. E (5th ed. 1946); HENRY SIMON, ECONOMIC POLICY FOR A FREE SOCIETY 71 (1948); and James M. Treece, Protectability of Product Differentiation: Is and Ought Compared, 18 RUTGERS L. REv. 1019, 1024-25 n.13 (1964).

11. See, e.g., William S. Comanor \& Thomas A. Wilson, AdVERTISING AND Market POWER 43-45 (1974) (collecting empirical evidence supporting Brown's market-differentiation argument); JEAN JACQUES LAMBIN, ADVERTISING, COMPETITION, AND MARKET CONDUCT IN OLIGOPOLY OVER TME 90-149 (1976) (presenting a comprehensive international study of the empirical effect of advertising); Lee Benham, The Effect of Advertising on the Price of Eyeglasses, 15 J.L. \& ECON. 337, 344-45 (1972) (including an empirical study suggesting that advertising reduces product cost); Thomas T. Nagle, Do Advertising-Profitability Studies Really Show That Advertising Creates a Barrier to Entry?, 24 J.L. \& ECON. 333, $344-47$ (1981) (summarizing and critiquing the empirical literature); I.P.L. Png \& David Reitman, Why Are Some Products Branded and Others Not?, 38 J.L. \& EcoN. 207, 212-19 (1995) (presenting empirical research on branded and unbranded gasoline). 
First, they have emphasized the efficiency by which trademarks and advertising communicate useful information to consumers, and thereby reduce consumer search costs. ${ }^{12}$ This communication function is particularly important with respect to what might be called "experience" characteristics of goods: those characteristics (such as taste, or perhaps durability) that consumers cannot readily verify except by buying the product. Advertising communicates these characteristics directly, and trademarks ensure that consumers associate the characteristics with the right product. It may also be important with respect to a class of goods called "reliance" goods, whose quality the consumer has little way of judging at all. ${ }^{13}$

Economists have also identified a second, "signaling" function of advertising. On this theory, advertising sends a self-referential message: In effect, "we advertise, and therefore we must sell a good of sufficiently high quality that we can afford this high-cost expenditure." 14

Finally, economists have pointed to the role of trademarks in allowing the growth of complex, long-term organizations spread over a wide geographic area. The ability to connote a variety of things by the use of a set of trademarks permits nationwide sales by a single entity, or alternatively the "franchising" of a trademark to independent producers overseen by the trademark owner. ${ }^{15}$ McDonald's would never have

12. See, e.g., Nicholas Economides, Trademarks, in THE NEW PALGRAVE DICTIONARY OF ECONOMICS AND THE LAW 601, 602-03 (Peter Newman ed., 1998) (arguing that trademarks "facilitate and enhance consumer decisions"); William P. Kratzke, Normative Economic Analysis of Trademark Law, 21 MEMPHS ST. U. L. REV. 199, 214-17 (1991) (arguing that trademarks are highly efficient means of conveying product information); Phillip Nelson, Advertising as Information, 82 J. POL. ECON. 729, 752 (1974) (arguing that the simple fact that a product is advertised conveys information about the "experience qualities" of that product); Phillip Nelson, Information and Consumer Behavior, 78 J. POL. ECON. 311, 323-25 (1970) (comparing the advantages of national versus retail advertising); George J. Stigler, The Economics of Information, 69 J. POL. ECON. 213, 220-24 (1961) (arguing that, although imperfect, advertising is a valuable means to reduce consumer ignorance). It is worth noting that Brown clearly anticipated and endorsed this justification for trademarks and advertising. See supra note 4 and accompanying text.

13. For a discussion of "inspection goods," experience goods, and reliance goods, see Dan L. Burk, Trademark Doctrines for Global Electronic Commerce, 49 S.C. L. REV. 695, 701 (1998). I follow Burk's taxonomy here.

14. For discussions of the signaling function of advertising, see J. Hirshleifer, Where Are We in the Theory of Information?, 63 AM. ECON. REV. PROC. 31, 37-38 (1973); Benjamin Klein \& Keith B. Leffler, The Role of Market Forces in Assuring Contractual Performance, 89 J. POL. ECON. 615, 630-31 (1981); Paul Milgrom \& John Roberts, Price and Advertising Signals of Product Quality, 94 J. POL. ECON. 796 (1986). Cf. George A. Akerlof, The Market for "Lemons": Quality Uncertainty and the Market Mechanism, 84 Q.J. ECON. 488, 499-500 (1970) (suggesting that without trademarks, the market for goods in which experience characteristics predominate would not be clear).

15. See, e.g., Mira Wilkins, The Neglected Intangible Asset: The Influence of the Trade Mark on the Rise of the Modern Corporation, 34 BUS. HIST., Jan. 1992, at 66, 87-88 ("Without the trade mark, the introduction and acceptance by buyers of modern products, produced with economies of scale or scope, and marketed over long distances, would have been impossible... The trade mark [sic] by reducing the costs of information led to efficiencies in 
achieved national prominence to travelers without strong trademarks and advertising. Similarly, the general acceptance today of the principle that trademarks can be licensed to others, at least under some circumstances, reflects a world in which the production of goods is less tied to a particular corporate structure than ever before. ${ }^{16}$

Many economists and lawyers in the past fifty years have challenged the "monopoly phobia" allegedly exhibited by Brown, Edward Chamberlain, ${ }^{17}$ and their contemporaries. ${ }^{18}$ These scholars start from the presumption that brand names and advertising perform useful social functions and contribute to the economy. ${ }^{19}$ This difference in approach surely cannot be attributed to any decline in the significance of "persuasive" as opposed to "informative" advertising; indeed, persuasive advertising has grown beyond what anyone studying the field in 1948 could have imagined..$^{20}$ It might be attributed to the new economic learning, at least in part. Certainly, the work of Nelson and others has given us a greater appreciation for the positive benefits of brand identification-benefits that Brown seemed to doubt. ${ }^{21}$ To give just one example, Brown asserts that

production and distribution."); see also Susser v. Carvel Corp., 206 F. Supp. 636, 640 (S.D.N.Y. 1962) (calling trademarks "the cornerstone of a franchise system"); James M. Treece, Trademark Licensing and Vertical Restraints in Franchising Arrangements, 116 U. PA. L. REV. 435, 445-48 (1968) (describing the role of trademarks in franchising).

16. See generally OLIVER WILLIAMSON, ECONOMIC ORGANZATION (1986) (discussing comparative institutional structure in transaction costs terms).

17. See ChamberLAIN, supra note 10.

18. See, e.g., Beverly W. Pattishall, Trade-marks and the Monopoly Phobia, $50 \mathrm{MrCH}$. L. REV. 967 (1952).

19. See, e.g., Benjamin Klein \& Keith B. Leffler, The Role of Market Forces in Assuring Contractual Performance, 89 J. POL. ECON. 615, 629-33 (1981); William M. Landes \& Richard A. Posner, Trade-mark Law: An Economic Perspective, 30 J.L. \& ECON. 265, $274-75$ (1987). For contrary views, see COMANOR \& WiLSON, supra note 11, at 240-52; and Glynn Lunney, Trademark Monopolies 7 (Jan. 15, 1999) (working paper, on file with The Yale Law Journal).

20. Brown complained about the pervasive influence of persuasive advertising in 1947, when U.S. corporations spent about $\$ 3.9$ billion on advertising. See Brown, supra note 1, at 1166-67 n.7. Today, they spend an estimated $\$ 112.4$ billion. See AdvertisingAge, Ad Age Dataplace (visited Jan. 31, 1999) <http://adage.com/dataplace/topmarkets/us.html>.

21. The new economic learning does not all support advertising, however. In particular, the economics of game theory - a discipline in its infancy when Brown wrote his article-offers an arguably inefficient explanation for advertising. See generally WILLIAM POUNDSTONE, PRISONER'S DILEMMA 8-9 (1992) (describing various applications of the prisoner's dilemma). On this theory, advertising may result from a "prisoner's dilemma": Both participants in the market (say, Coke and Pepsi) would be better off not advertising, but each will lose out if its opponent advertises and it does not, so both firms decide to advertise. I think this may well be an accurate description of what is going on in many cases. Unfortunately, as with much of game theory, it is hard to draw robust conclusions from the model about whether this behavior is socially optimal. Certainly, the firms in the prisoner's dilemma model would be better off if they could get together and agree in some binding way not to advertise. But would the public be better off as a result? Not necessarily. This agreement between firms might be a cartel, an agreement not to compete on a salient characteristic of interest to consumers. Whether the outcome of the prisoner's dilemma is socially optimal depends on whether a cutback in advertising is good or bad-precisely the question we seek to answer. Determining the answer to that question in any given case would 
bread "is in fact pretty much standardized," so that there is no reason for advertising to differentiate bread products. ${ }^{22}$ In fact, however, the modern world features an enormous diversity not only of kinds of bread, but also of qualities of bread. Thus, this example might suggest that the product differentiation facilitated by trademarks is helping consumers choose the optimal bread for them.

But surely this cannot be the whole explanation. There seems no question that advertising contributes to product differentiation not only on the basis of quality, but also among goods of demonstrably identical quality, such as pharmaceuticals. ${ }^{23}$ It is hard to construct a plausible case for product differentiation in such a circumstance. By contrast, the costs of artificial brand differentiation in terms of power over price are quite clear. ${ }^{24}$ While advertising may still lower search costs, the participation of government and private agencies that provide consumer information-the Federal Drug Administration (FDA), Consumer Reports, the Better Business Bureau, and even supermarkets and other stores that stock multiple brands-can sometimes be just as effective as advertising.

So why is there no serious hostility to advertising and trademark law among economists today? There are several reasons, some good and some bad. First, economists today are much more reluctant to second-guess the workings of the market than they were fifty years ago. Brown's distinction between informational and persuasive advertising ${ }^{25}$ is troubling because it impels him to conclude that an enormous number of consumers do not really want what they think they want; they have been duped by unscrupulous marketers. Perhaps I am a product of my own generation, but I am loath to jump to such a conclusion. My preference for Diet Coke over Diet Pepsi or any other cola drink may be an irrational one, induced by childhood memories of teaching the world to sing or some similar

require an inquiry into any possible informative, market-expanding, market-disciplining, persuasive, or misleading effects the advertising itself would have.

22. Brown, supra note 1 , at 1179 n.59.

23. Indeed, trademarks themselves might support this artificial differentiation, as where similar goods from the same manufacturer are given different names in an effort to appeal to different market segments at different prices.

24. See, e.g., Denicola, supra note $\dagger$, at 1663; Lunney, supra note 19, (manuscript at 6-7). For example, a brief trip to the drugstore will convince anyone that branded drugs cost much more than their generic counterparts, despite having identical ingredients. Brown noted the same phenomenon in his day. See Brown, supra note 1, at 1173 . Indeed, companies periodically sell identical products under different brands-and at different prices. See, e.g., Bloor v. Falstaff Brewing Corp., 601 F.2d 609, 614 (2d Cir. 1979) (noting that Falstaff sold its house brand and its Ballantine brand at different prices "despite identity of the ingredients").

25. See Brown, supra note 1, at 1182-84. 
promotional effort. But in a free market economy, perhaps the choice should be mine to make, for good or ill. ${ }^{26}$

Second, the economy of 1998 is very different from the economy of 1948. Transactions in services, information, and intellectual property are a growing percentage of the economy. ${ }^{27}$ It may be that advertising and brand loyalty are more important in such transactions than they are in the relatively homogenous world of old. Services have many experience characteristics; those who are purchasing an ongoing relationship will need information other than merely price. Similarly, in industries characterized by rapid innovation, a product's quality characteristics may be much more important than its price characteristics over the medium run. Companies who compete on these nonprice characteristics generally must advertise them. Other markets may also require particular sorts of advertising. ${ }^{28}$ Further, as markets become national and international in scope and customers become more mobile, the role of trademarks in creating a reputation that extends beyond a limited geographic area becomes more important. $^{29}$ In short, as the subject matter of commercial transactions becomes more complex and less tangible, reputation becomes more central. On this theory, Brown's views about advertising might be thought outmoded. Perhaps we need advertising (and trademarks) more now than we did in a simpler world.

Finally, there is an increasing tendency to treat trademarks as assets with their own intrinsic value, rather than as a means to an end. In part, this change reflects a broader trend towards "propertizing" intellectual property, a phenomenon that I have described elsewhere. ${ }^{30}$ Someone who thinks of trademarks as equivalent to real or personal property probably will not share Brown's hostility to advertising. Indeed, they may not even think

26. Glynn Lunney questions whether this deference is appropriate: "Were Pavlov's dogs happier after they had been trained to salivate at the sound of a dinner bell?" Lunney, supra note 19 (manuscript at $58 \mathrm{n} .201$ ).

27. See Steven Weber, The End of the Business Cycle?, ForEIGN AFr., July 1997, at 65 (noting that exports of intangibles alone account for up to 10 percent of the U.S. economy).

28. For example, it is common in network markets for companies to advertise their market share. See Mark A. Lemley, Antitrust and the Internet Standardization Problem, 28 CONN. L. REV. 1041, 1041 (1996). Presumably, companies advertise this way to take advantage of the fact that consumers in such a market are likely to prefer to buy the product everyone else is buyingfor rational economic reasons. See generally Mark A. Lemley \& David McGowan, Legal Implications of Network Economic Effects, 86 CAL. L. REV. 479 (1998) (explaining the nature of network markets).

29. See Marshall A. Leaffer, The New World of International Trademark Law, 2 MARQ. INTELL. PROP. L. REV. 1, 4-5 (1998).

30. See Mark A. Lemley, Romantic Authorship and the Rhetoric of Property, 75 TEX. L. REv. 873, 895-904 (1997) (reviewing JAMES BOYLE, SHAMANS, SOFTWARE, AND SPLEENS: LAW AND THE CONSTRUCTION OF THE INFORMATION SOCIETY (1996)). To be sure, the concept of trademarks as property is not itself a new one. Cohen criticized it as early as 1935. See Cohen, supra note 5, at $814-17$. But the law seems to have gravitated towards this approach in recent years. 
it worth asking whether advertising is good or bad, any more than they would second-guess the style of house that someone built on their land.

I think this last explanation-treating trademarks as property-is a remarkable trend worthy of further attention. Why should the law create property rights in trademarks, particularly the strong, unfettered property rights that seem to underlie the "trademarks as property" concept? We don't protect trademarks to encourage the creation of more trademarks, and so the incentive rationale for intellectual property will not work here. ${ }^{31}$ Trademarks may be valuable as vehicles for efficient advertising; protecting their owners against the use of confusingly similar marks will encourage investment in brand quality and simultaneously protect consumers from confusion. ${ }^{32}$ But if we are to conclude that the trademark itself is valuable property, we need some rationale beyond these traditional justifications for trademark law.

That rationale turns out to be hard to find, as Brown predicted. ${ }^{33}$ The new economic learning on brands and advertising ties trademarks to consumer search costs and experience characteristics. But none of these changes has undermined the basic differences among trademarks and other forms of intellectual property. Patents and copyrights are created for an instrumental purpose that is directly related to the subject matter of protection: We want more of the sort of works that patent and copyright law protect. One can construct from this an argument that we should vest the creators of those works with strong property rights, as rewards, incentives,

31. See Landes \& Posner, supra note 19, at 268-73. The Supreme Court drew a sharp distinction between trademarks and other forms of intellectual property in the Trade-Mark Cases, 100 U.S. 82, 93-94 (1879). There it noted that trademarks do not themselves "depend upon novelty, invention, discovery, or any work of the brain. It requires no fancy or imagination, no genius, no laborious thought." Id.; $c f$. ROBERT P. MERGES ET AL., INTELLECTUAL PROPERTY IN THE NEW TECHNOLOGICAL AGE 525 (1997) (noting that the rationale for trademark law differs from that for other forms of intellectual property).

32. See MERGES ET AL., supra note 31, at 526.

33. See Brown, supra note 1 , at 1199 . Let me be clear that I am focusing here only on economic justifications, not other possible philosophical rationales. Still, none of the most common alternative rationales for intellectual property offer much support for a strong property right in trademarks either. See, e.g., Wendy J. Gordon, A Property Right in Self-Expression: Equality and Individualism in the Natural Law of Intellectual Property, 102 YALE L.J. 1533, 1600 (1993) [hereinafter Gordon, Self-Expression]. But see Simone A. Rose, Will Atlas Shrug? Dilution Protection for "Famous" Trademarks: Anti-Competitive "Monopoly" or Earned "Property" Right?, 47 FLA. L. REV. 653, 688-90 (1995) (basing an argument for dilution protection on natural law and personality theory).

Kratzke has effectively deconstructed the "free riding" or "unjust enrichment" argument against the use of trademarks by competitors. See Kratzke, supra note 12, at 223. In short, Kratzke argues that to call competitive behavior "free riding" is a conclusionary epithet, not a workable economic principle. See id. Free riding is good-indeed, it is the essence of competition-unless there is some reason to think it will lead to a market failure. Were it not for free riding, everything we did, bought, or used would either be purchased at a monopoly price (probably with perfect price discrimination). Cf. Wendy J. Gordon, On Owning Information: Intellectual Property and the Restitutionary Impulse, 78 VA. L. REV. 149, 167 (1992) ("A culture could not exist if all free riding were prohibited within it."). 
or inducements to continued investment. ${ }^{34}$ This is not a necessary conclusion; indeed, for a variety of reasons it is probably wrong to treat patents and copyrights as analogous to real property. ${ }^{35}$ Even if one accepts this rationale for other intellectual property rights, however, it does not carry over to trademarks. ${ }^{36}$ The justifications for trademark law are different from those for other forms of intellectual property.

We give protection to trademarks for one basic reason: to enable the public to identify easily a particular product from a particular source. Allowing this connection to be made in turn has secondary benefits: Consumer surplus is not diminished by fraud; producers can compete on the basis of experience characteristics of goods, and so on. There is no reason to believe that treating trademarks as property is particularly likely to further this goal. ${ }^{37}$ After all, we don't necessarily want more new trademarks as an end in itself. ${ }^{38}$ Indeed, we might all be better off in a world with fewer brands clamoring for our scarce attention, and less of the artificial product differentiation Brown derided. Even if we did want more trademarks for some reason, it is far from clear that we would need government-provided incentives to create them. ${ }^{39}$ Further, the economic case for brands and advertising is undone to the extent that trademarks are used in ways that affirmatively confuse consumers. Vesting trademarks

34. See KENNETH W. DAM, INTELlECTUAL PROPERTY IN AN AGE OF SOFTWARE AND BioteChNology 4 (Chicago Law \& Econ. Working Paper No. 35, 1995); Trotter Hardy, Property (and Copyright) in Cyberspace, 1996 U. CHI. LEGAL F. 217, 219-26; Edmund W. Kitch, The Nature and Function of the Patent System, 20 J.L. \& ECON. 265, 275-80 (1977); Edmund W. Kitch, Patents: Monopolies or Property Rights?, 8 RES. L. \& ECON. 31 (1986).

35. See Julie E. Cohen, Lochner in Cyberspace: The New Economic Orthodoxy of Rights Management, 97 MICH. L. REV. 462, 495-515 (1998); Mark A. Lemley, The Economics of Improvement in Intellectual Property Law, 75 TEX. L. REV. 989, 1048-72 (1997); Lemley, supra note 30, at 902-03.

36. See, e.g., Cohen, supra note 5, at 814-15; Kenneth L. Port, The Illegitimacy of Trademark Incontestability, 26 IND. L. REV. 519, 552-63 (1993) (noting the numerous differences between trademarks and other forms of intellectual property).

37. William Kratzke argues that ownership of trademarks is, like much real property, designed to solve the problem of overuse of a "commons" of speech involving trademarks. Nonetheless, he notes, treating trademarks as property to which trademark owners are ipso facto entitled "puts the cart before the horse," because it assumes that there is a public policy justification for creating such property. Kratzke, supra note 12, at 203-04; see also Frank Schechter, Fog and Fiction in Trade-Mark Protection, 36 CoLUM. L. REV. 60, 65 (1936) (contending that calling trademarks "property" does not help understand the proper scope of trademark protection).

38. See, e.g., Gordon, Self-Expression, supra note 33, at 1588 n.277 (1993) ("Usually a trademark is not purposely created for its own sake; the 'benefit' purposely created is the good will of the owning entity... which the trademark merely happens to represent.").

39. See, e.g., Ambrosia Chocolate Co. v. Ambrosia Cake Bakery, 165 F.2d 693, 697 (4th Cir. 1947) (" $[A]$ man of ordinary intelligence could easily devise a score of valid trade-marks in a short period of time."); Rochelle Cooper Dreyfuss, Expressive Genericity: Trademarks as Language in the Pepsi Generation, 65 NOTRE DAME L. REV. 397, 399 (1990) ("[T]here is little need to create economic incentives to encourage businesses to develop a vocabulary with which to conduct commerce."). But cf. Landes \& Posner, supra note 19, at 270 (suggesting that trademark protection offers a modest incentive to create new marks). 
with the mantle of property-and giving them some of the indicia of real property, such as free transferability-defeats the purpose of linking trademarks to goods in the first place.

Even more troubling, propertizing trademarks comes at a rather significant cost to society. Sometimes that cost takes the form of lost opportunities: Important political and social commentary and works of art may be suppressed entirely. It may also take the form of higher prices: When we protect the design of products as trademarks, we prevent competition in the sale of those products, and the price goes up accordingly. Other social costs are more diffuse, but no less real: Our language and our culture are impoverished when we cannot use the most familiar words to discuss-or make fun of, or criticize - the products and companies that are the basis of our economy. At the very least, it becomes inconvenient to do so. ${ }^{40}$ And perhaps most important, trademark licensing is expensive. ${ }^{41}$ The more we propertize, the more transaction costs we impose on everyone. Companies and individuals will have to hire more lawyers, delay introducing their products, and spend money in merchandising fees to acquire the rights to use words, logos, or product configurations. Because trademarks so often overlap, propertization may also reduce certainty, making trademark searching and clearance more difficult and leading to more litigation.

Treating trademarks as property also creates abundant incentives for opportunistic behavior. If trademarks are property, it becomes harder to explain why they do not always belong to whoever grabs them first. The property theory has already led some people to register marks not to be used to identify the source of goods, but solely to lock up the use of the trademarked phrase itself. Thus, one legal entrepreneur has registered "Class of 2000" as a trademark and claims the right to prevent anyone else from selling merchandise bearing the phrase. ${ }^{42}$ Another has registered the ubiquitous yellow smiley-face and is collecting money from those who use

40. See Robert C. Denicola, Trademarks as Speech: Constitutional Implications of the Emerging Rationales for the Protection of Trade Symbols, 1982 WIS. L. REV. 158, 195-96 ("Famous trademarks offer a particularly powerful means of conjuring up the image of their owners, and thus become an important, perhaps at times indispensable, part of the public vocabulary. Rules restricting the use of well-known trademarks may therefore restrict the communication of ideas."). Gordon notes that a related problem justifies the doctrine of genericide, under which standard terms cannot be exclusively owned. See Gordon, SelfExpression, supra note 33, at 1600 \& n.364. Creating circumlocutions to avoid trademarks is costly. See Ralph H. Folsom \& Larry L. Teply, Trademarked Generic Words, 89 YALE L.J. 1323, 1340-42 (1980); Landes \& Posner, supra note 19, at 280, 292.

41. See Paul Heald, Sunbeam Products, Inc. v. The West Bend Co.: Exposing the Malign Application of the Federal Dilution Statute to Product Configurations, 5 J. INTELL. PROP. L. 415, 427-28 (1998) (arguing that property-like rights in trademarks raise prices).

42. See Seeking Riches with "Class of 2000", N.Y. TrMES, Oct. 7, 1998, at B8. 
it. ${ }^{43}$ Still another (not the movie producer) claims the exclusive right to sell merchandise with the word "Titanic" on it. ${ }^{44}$ Under traditional trademark law, these claims are frivolous. Trademark law protects source identification; it does not allow people to own designs or phrases outright and to prevent their use regardless of context. Get a copyright, if you can; if not, too bad. But as trademarks continue to be treated as property, it becomes harder and harder to come up with a convincing reason why one should not be allowed to register "Class of 2000" or the smiley-face and prevent anyone else from using them without a license. Rochelle Dreyfuss has complained of the "privatization" of words and phrases; ${ }^{45}$ recent cases make it clear that this is not an abstract concern.

In short, the economics of trademark law has grown more sophisticated over the last fifty years, but it has not abandoned its roots. The economic rationale for trademarks today is roughly the same as it was a half-century ago. Unfortunately, the law is quite different. And so Brown's concern with linking trademark doctrine to trademark theory has renewed importance today.

\section{THE EXPANDING BOUNDARIES OF TRADEMARK RIGHTS}

Courts seem to be replacing the traditional rationale for trademark law with a conception of trademarks as property rights, in which trademark "owners" are given strong rights over the marks without much regard for the social costs of such rights. There appear to be three basic parts to this trend. First, we sometimes seem to be making trademark law for the extreme case, but we then apply that law to a large number of run-of-themill trademarks. Second, courts increasingly treat brands as things owned in their own right, rather than as advertising connected with a particular product. Finally, courts have not been sufficiently sensitive to legitimate free speech concerns in cases where trademark owners seek to restrict noncompetitive uses of the trademark.

\section{A. Making Law for the Extreme Case}

In a number of recent instances, trademark law has been expanded quite significantly by means of new legal rules that make sense in a limited number of cases, but that then enter widespread use where they make less

43. See Matthew Kauffman, Smiley Face Creator Fails To Win Royalties but Seeks Last Laugh, SAN JOSE MERCURY NEwS, Sept. 24, 1998, at E1.

44. See James Schembari, Who Owns the Name Titanic?, N.Y. TimES, Feb. 11, 1999, at A27.

45. See Rochelle Cooper Dreyfuss, We Are Symbols and Inhabit Symbols, So Should We Be Paying Rent? Deconstructing the Lanham Act and Rights of Publicity, 20 CoLUM.-VLA J.L. \& ARTS 123, 128 (1996). 
sense. The tendency is perhaps a natural one. If Congress creates a new statute that protects some but not all trademark owners, every trademark owner will want his or her mark to be included in the new group and will seek to receive the added protections of the new rule. If courts are not careful to restrain the new doctrine, it will soon take on a life of its own. I call this the problem of "doctrinal creep."

\section{Dilution}

The most obvious example of doctrinal creep in trademark law is dilution. Dilution laws are directed against the possibility that the unique nature of a mark will be destroyed by companies who trade on the renown of the mark by selling unrelated goods, such as Kodak pianos or Buick aspirin. ${ }^{46}$ But because consumers need not be confused for dilution to occur, dilution laws represent a fundamental shift in the nature of trademark protection.

Dilution laws are largely a product of the last fifty years. Approximately half of the states now have dilution statutes. But most recent attention has been focused on the federal dilution statute, which was added in 1995. The federal statute, like most state dilution statutes, protects only "famous" marks. ${ }^{47}$ The statute offers a nonexclusive list of eight factors for courts to consider in determining whether a mark is "distinctive and famous." ${ }^{48}$ The clear intention seems to have been to restrict dilution doctrine to a relatively small class of nationally known trademarks whose fame is sufficiently great that the risk of blurring by multiple noncompeting uses is significant. ${ }^{49}$ But courts applying the state and federal dilution statutes have been quite willing to conclude that a local favorite, or a rather obscure company, is "famous" within the meaning of the Act. Thus, marks such as Intermatic, Gazette, Dennison, Nailtiques, TeleTech, Wedgewood (for new homes, not china), Papal Visit 1999, and Wawa have been declared famous. ${ }^{50}$ Worse, many courts seem willing to find dilution

46. See H.R. REP. No. 104-374, at 3 (1995). For early discussion of dilution theories, see Frank I. Schechter, The Rational Basis of Trademark Protection, 40 HARV. L. REV. 813 (1927). Brown was quite critical of dilution theory. See Brown, supra note 1, at 1191-94.

47. See 15 U.S.C. $\$ 1125$ (c) (1994).

48. Id. The factors include the strength of the mark, the length and breadth of the use, the extent of advertising of the mark, its public recognition, how close existing marks are, and whether the mark is registered. See id. The legislative history of the Act indicates that "famous marks ordinarily are used on a nationwide basis." H.R. REP. NO.104-374, at 3 (1995).

49. See, e.g., H.R. REP. No. 104-374, at 7 (1995) ("[G]enerally a famous mark will have been in use for some time. The geographic fame of the mark must extend throughout a substantial portion of the U.S.").

50. See Archdiocese of St. Louis v. Internet Entertainment Group, Inc., No. 4:99CV27SNL, 1999 WL 66022, at *1 (E.D. Mo. Feb. 12, 1999) (holding "Papal Visit 1999" famous for the Pope's recent visit to St. Louis); Avery Dennison Corp. v. Sumpton, 999 F. Supp. 1337, 1340-41 (C.D. Cal. 1998) (holding "Dennison" famous as part of Avery-Dennison corporate name); 
without even inquiring into the fame of the mark. ${ }^{51}$ Dilution doctrine has also been expanded to encompass not only noncompeting but also nonidentical marks, ${ }^{52}$ to protect famous trade dress and product configurations, ${ }^{53}$ to attack longstanding uses of descriptive marks to describe products, ${ }^{54}$ to aid trademark owners in ordinary cases against competitive marks by dispensing with the need to demonstrate consumer confusion, ${ }^{55}$ and even to create a cause of action against consumers (or the press) who do not use marks properly. ${ }^{56}$ While the federal law is still relatively new, and so prediction is difficult, we may be moving toward a world in which "famous" marks protected even in the absence of consumer confusion are the rule rather than the exception. The result, as one commentator has noted, is to grant a "trademark in gross"-one unconnected to a particular product-to a wide variety of owners.

Nailtiques Cosmetic Corp. v. Salon Sciences Corp., 41 U.S.P.Q.2d 1995, 1998-99 (S.D. Fla. 1997 ) (holding "Nailtiques" famous for fingernail care products and diluted by "ProTechniques"); Tele'Tech Customer Care Management (California) v. Tele-Tech Co., 977 F. Supp. 1407, 1413 (C.D. Cal. 1997) (finding "TeleTech" "probably famous" for customer care information services and that "teletech.com" was infringing but "tele-tech.com" was not); Gazette Newspapers v. The New Paper, Inc., 934 F. Supp. 688, 693, 696 (D. Md. 1996) (holding "Gazette" famous for local Maryland paper); Intermatic, Inc. v. Toeppen, 947 F. Supp. 1227, 1236 (N.D. Ill. 1996) (holding "Intermatic" famous for electrical products); Wawa, Inc. v. Haaf, 40 U.S.P.Q.2d 1629, 1630 (E.D. Pa. 1996) (holding "Wawa" famous for convenience stores in Pennsylvania and surrounding states); Wedgwood Homes, Inc. v. Lund, 659 P.2d 377, 380 (Or. 1983) (holding "Wedgwood" famous for house builders in eastern Washington County, Oregon).

51. One commentator reports that of the 16 cases she examined, "half did not make an explicit finding that the mark in question was famous, or made such a finding only by confusing fame with distinctiveness." Lori Krafte-Jacobs, Comment, Judicial Interpretation of the Federal Trademark Dilution Act of 1995, 66 U. CIN. L. REV. 659, 690 (1998) (citation omitted).

52. See, e.g., Ringling Bros.-Barnum \& Bailey, Combined Shows, Inc. v. Utah Div. of Travel Dev., 935 F. Supp. 763, 765-66 (E.D. Va. 1996) ("The Greatest Show on Earth" v. "The Greatest Snow on Earth"); Toys "R" Us Inc. v. Akkaoui, 40 U.S.P.Q.2d 1836 (N.D. Cal. 1996) ("Toys 'R' Us" v. "Adults 'R' Us").

53. Sunbeam Prods. v. West Bend Co., 39 U.S.P.Q.2d 1545, 1548 (S.D. Miss. 1996), aff d, 123 F.3d 246, 251 (5th Cir. 1997); cf. I.P. Lund Trading v. Kohler Co., 163 F.3d 27, 35, 45, 51 (1st Cir. 1998) (assuming that the dilution statute applies to trade dress but refusing to apply it in this case). Paul Heald has been especially critical of this development, calling the district court decision in Sunbeam the "worst [intellectual property] opinion" ever written. See Heald, supra note 41 , at 415 . Heald argues that the dilution statute cannot plausibly be construed to apply to trade dress and product configurations, as opposed to word marks. He also notes that patent law has been vigilant in preventing such protection by states. See id. at 423-24 (citing Bonito Boats, Inc. v. Thunder Craft Boats, Inc., 489 U.S. 141 (1989)).

54. See Westchester Media Co. v. PRL USA Holdings, Civil Action No. H-97-3278, 1998 U.S. Dist. Lexis 11735 , at *28 (S.D. Tex. July 2, 1998) (holding that Polo Magazine could continue to use the "Polo" mark Ralph Lauren made famous in writing about the sport of polo, but only if it included a disclaimer).

55. See, e.g., Deere \& Co. v. MTD Prods., 41 F.3d 39, 44 (2d Cir. 1994).

56. The rationale here is "contributory dilution"-that individuals who use a mark generically, or media who do not treat it as a brand name, are contributing to the loss of distinctive significance of the mark. For a discussion of this new theory, see Sean K. Murphy, Note, When "March Madness" Came Back to Chicago, 1998 Wis. L. REv. 1337, 1372-73. Contributory dilution may be the most pernicious concept ever to come out of trademark theory.

57. Howard J. Shire, Dilution Versus Deception-Are State Antidilution Laws an Appropriate Alternative to the Law of Infringement?, 77 TRADEMARK REP. 273, 296 (1987); see 


\section{Product Configurations}

Something similar is happening with product configurations. Courts have recognized for some time that the trade dress of a product, and in certain cases even the shape of the product itself, might qualify for trademark protection. A classic example might be the shape of the traditional Coca-Cola bottle, which clearly serves as an indicator of source to a large number of consumers. Product configurations can be registered, and even unregistered configurations can be protected under section 43(a) ${ }^{58}$ Still, until recently, attempts to protect the shape or appearance of goods themselves were relatively rare. Even court decisions permitting such protection, like Qualitex Co. v. Jacobson Products Co. ${ }^{59}$ made it clear that it was unusual for the shape of a product actually to serve a sourceidentifying function. ${ }^{60}$

In the last fifteen years, product configuration cases have exploded onto the trademark scene. ${ }^{61}$ Companies have successfully claimed trademark rights in the décor of a restaurant, ${ }^{62}$ an artistic style of painting, ${ }^{63}$ the design of a golf course, ${ }^{64}$ the shape of a faucet handle, ${ }^{65}$ the diamond shape of a lollipop, ${ }^{66}$ the unique registration process of a toy fair, ${ }^{67}$ the shape of a mixer, ${ }^{63}$ and the design of personal organizers ${ }^{69}$ and they have sought

also Kenneth L. Port, The "Unnatural" Expansion of Trademark Rights: Is a Federal Dilution Statute Necessary?, 18 SETON HALL LEGIS. J. 433, 447-49 (1994) (questioning the need for a federal dilution statute).

58. Lanham Act, Pub. L. No. $79-489$ § 43(a) (1946) (codified at 15 U.S.C. \$ 1125(a) (1994)).

59. 514 U.S. 159,174 (1995) (permitting the maker of dry cleaning pads to protect the wellknown and distinctive color of the pads).

60. See RESTATEMENT (THIRD) OF UNFAIR COMPETITION $\$ 16$ cmt. b (1995):

The imitation or even complete duplication of another's product or packaging will not create a risk of confusion unless some aspect of the duplicated appearance is identified with a particular source. ... As a practical matter, however, it is less common for consumers to recognize the design of a product or product feature as an indication of source. Product designs are more likely to be seen merely as utilitarian or ornamental aspects of the goods.

61. For detailed discussion of this development, see Margreth Barrett, Trade Dress Protection for Product Configurations and the Federal Right To Copy, 20 Hastings COMM. \& ENT. L.J. 471 (1998); Graeme B. Dinwoodie, Reconceptualizing the Inherent Distinctiveness of Product Design Trade Dress, 75 N.C. L. REV. 471 (1997); and A. Samuel Oddi, Product Simulation: From Tort to Intellectual Property, 88 TRADEMARK RPTR. 101 (1998).

62. See Two Pesos, Inc. v. Taco Cabana, Inc., 505 U.S. 763, 770 (1992).

63. See Romm Art Creations Ltd. v. Simcha Int'l, 786 F. Supp. 1126, 1141 (E.D.N.Y. 1992).

64. See Pebble Beach Co. v. Tour 18 I Ltd., 155 F.3d 526, 537-43 (5th Cir. 1998) (holding that the design of a golf hole with a view of a lighthouse was entitled to trade dress protection because it had acquired secondary meaning, but that other features of the course were not protectable).

65. See Kohler Co. v. Moen, Inc., 12 F.3d 632, 643-44 (7th Cir. 1993).

66. See Topps Co. v. Gerrit J. Verburg Co., 41 U.S.P.Q.2d 1412, 1416 (S.D.N.Y. 1996).

67. See Toy Mfrs. of Am. v. Helmsley-Spear, Inc., 960 F. Supp. 673, 680 (S.D.N.Y. 1997).

68. See Sunbeam Prods., v. West Bend Co., 123 F.3d 246, 252-57 (5th Cir. 1997).

69. See Stuart Hall Co. v. Ampad Corp., 51 F.3d 780, 788-90 (8th Cir. 1995). 
protection for sweater patterns, ${ }^{70}$ the shape of troll dolls,${ }^{71}$ the shape of a building, ${ }^{72}$ the helical blade of fans, ${ }^{73}$ the shape of cable ties, ${ }^{74}$ and the shape of Grecian-urn-style plastic planters. ${ }^{75}$ Some plaintiffs have even succeeded in protecting as product configurations the very features of their products for which they had previously received a patent. ${ }^{76}$

As with dilution, what started as an exceptional doctrine for cases in which the risk to goodwill was evident has expanded into a trademark doctrine of general applicability, one that virtually any manufacturer can invoke to secure additional protection for its products. In the process, the - link between product configuration and consumer source identification has all but disappeared. Once Two Pesos declared that "inherently distinctive" trade dress and product configurations were entitled to automatic protection, ${ }^{77}$ numerous plaintiffs who could plausibly characterize their product configuration as "arbitrary" or even "suggestive" sought automatic protection for the shape of their products. ${ }^{78}$

\section{Cybersquatters and Domain Names}

Courts have also stretched trademark doctrine to accommodate the extreme case involving Internet domain names and "cybersquatters."

70. See Knitwaves Inc. v. Lollytogs Ltd., 71 F.3d 996, 1006 (2d Cir. 1995).

71. See EFS Mktg. v. Russ Berrie \& Co., 76 F.3d 487, 489 (2d Cir. 1996).

72. See Rock \& Roll Hall of Fame \& Museum v. Gentile Prods., 134 F.3d 749, 753 (6th Cir. 1998).

73. See Vornado Air Circulation Sys. v. Duracraft Corp., 58 F.3d 1498, 1503 (10th Cir. 1995).

74. See Thomas \& Betts Corp. v. Panduit Corp., 65 F.3d 654, 656 (7th Cir. 1995).

75. See Duraco Prods. v. Joy Plastic Enters., 40 F.3d 1431, 1436 (3d Cir. 1994).

76. See, e.g., Thomas \& Betts Corp. v. Panduit Corp., 138 F.3d 277, 283 (7th Cir. 1998) (concluding that product configuration could be protected even though the overall product was patented). But see Vornado Air Circulation Sys., 58 F.3d at 1500 (holding product configuration protection unavailable where the configuration at issue was a "significant inventive component" of an invention covered by an expired utility patent). For a discussion of this issue, see Thomas Cotter, Is This Conflict Really Necessary?: Resolving an Ostensible Conflict Between Patent Law and Federal Trademark Law (Jan. 18, 1999) (working paper, on file with The Yale Law Journal). Cotter advocates protecting patented features under trademark law, provided the functionality doctrine is strictly applied to limit such protection. Id. (manuscript at 84).

77. Two Pesos, Inc. v. Taco Cabana, Inc., 505 U.S. 763, 776 (1992).

78. The classification of trade dress and product configurations as "descriptive," "suggestive," or "arbitrary," the categories used for word marks, is frequently nonsensical. Some circuits have rejected this classification scheme in favor of an inquiry into whether the product configuration is "likely to serve primarily as a designator of origin of the product." Duraco Prods., 40 F.3d at 1440-41, quoted in EFS Mktg. v. Russ Berrie \& Co., 76 F.3d 487, 491 (2d Cir. 1996), and Knitwaves, Inc. v. Lollytogs Ltd., 71 F.3d 996, 1008 (2d Cir. 1995). While this approach makes sense, it is arguably inconsistent with Two Pesos, where the Supreme Court held that the same standards applied to trade dress as to word marks. Two Pesos, 505 U.S. at 773. But cf. Qualitex Co. v. Jacobson Prods., 514 U.S. 159, 166 (1995) (suggesting that color can be protected only on a finding of secondary meaning). For a discussion of this problem, see Michael B. Landau, Reconciling Qualitex with Two Pesos: Ambiguity and Inconsistency from the Supreme Court, 3 UCLA ENT. L. REV. 219 (1996). 
Cybersquatters like Dennis Toeppen acted early to lock up a number of Internet domain names that reflect trademarks or corporate names, for a variety of possible purposes. Courts that have considered suits by trademark owners against cybersquatters have uniformly held that obtaining someone else's trademark as a domain name is either trademark infringement or dilution. ${ }^{79}$ In many cases, this is clearly the right result. If I register my competitor's name on the Internet, so that potential customers who enter that name will arrive at my site instead, I am clearly creating confusion in an attempt to profit commercially. ${ }^{80}$ In other cases, though, courts have had to stretch the "commercial use in commerce" requirement to the vanishing point in order to "catch" cybersquatters. Thus, courts have held that owning a domain name that you do not use is "use in commerce" if you hope to sell the domain name to the trademark owner. ${ }^{81}$ And several courts have even held that noncommercial use of a domain name is "commercial use in commerce," reasoning that any use on the Internet is automatically a use in commerce. ${ }^{82}$ This is in striking contrast to the meaning of the term in ordinary trademark cases. ${ }^{83}$

79. See, e.g., Panavision Int'l v. Toeppen, 141 F.3d 1316, 1327 (9th Cir. 1998); Jews for Jesus v. Brodsky, 993 F. Supp. 282, 306-07 (D.N.J. 1998); Cardservice Int'l v. McGee, 950 F. Supp. 737, 742 (E.D. Va. 1997); Lozano Enters. v. La Opinion Publ'g, 44 U.S.P.Q.2d (BNA) 1764, 1767 (C.D. Cal. 1997); Planned Parenthood Fed'n of Am. v. Bucci, 42 U.S.P.Q.2d (BNA) 1430, 1435-37 (S.D.N.Y. 1997); Comp Examiner Agency v. Juris, Inc., No. 96-0213-WMB (CTx), 1996 WL 376600, at*1 (C.D. Cal. May 22, 1996); Hasbro, Inc. v. Internet Entertainment Group Ltd., 40 U.S.P.Q.2d (BNA) 1479, 1480 (W.D. Wash. 1996); Intermatic, Inc. v. Toeppen, 947 F. Supp. 1227, 1239-41 (N.D. Ill. 1996); Toys “R” Us v. Akkaoui, 40 U.S.P.Q.2d (BNA) 1836,1838 (N.D. Cal. 1996).

80. Examples of this sort of conduct include the registration of "kaplan.com" by Princeton Review, Kaplan's principal competitor. See, e.g., Elizabeth Corcoran, Panel Backs Post Unit on Internet Address, WASH. POST, Oct. 7, 1994, at A04; Richard Raysman \& Peter Brown, On-Line Legal Issues, N.Y.L.J., Feb. 15, 1995, at 3 (discussing private arbitration in the case).

81. See, e.g., Panavision, 141 F.3d at 1324-26; Intermatic, 947 F. Supp. at 1239. But see Lockheed Martin Corp. v. Network Solutions, Inc., 985 F. Supp. 949, 957 (C.D. Cal. 1997) (finding that Network Solutions was not using a mark in commerce by issuing a domain name for a fee); Academy of Motion Picture Arts \& Sciences v. Network Solutions, Inc., 45 U.S.P.Q.2d (BNA) 1463,1466 (C.D. Cal. 1997) (same). And some courts have held that merely "reserving" a domain name by registering it is not trademark infringement, provided the defendant makes no use of the domain. See Juno Online Servs. v. Juno Lighting, Inc., 979 F. Supp. 684, 692-93 (N.D. Ill. 1997).

82. See Bucci, 42 U.S.P.Q.2d at 1434-35 ("The nature of the Internet indicates that establishing a typical home page on the Internet, for access to all users, would satisfy the Lanham Act's 'in commerce' requirement."); Jews for Jesus, 993 F. Supp. at 309. In Bucci, the defendant was an anti-abortion protester who registered "plannedparenthood.com" and used the site to post his political messages. See 42 U.S.P.Q.2d at 1432. In Jews for Jesus, the defendant registered "jewsforjesus.org" and devoted it to criticism of the plaintiff's religion. See 993 F. Supp. at 291.

83. See, e.g., Allard Enters. v. Advanced Programming Resources, 46 U.S.P.Q.2d (BNA) 1865,1870 (6th Cir. 1998) (noting that use in commerce means "the bona fide use of a mark in the ordinary course of trade and not made merely to reserve a mark" (quoting 15 U.S.C. \$ 1127 (1994)). Indeed, the divergence between the cybersquatting cases and normal dilution cases is so great that the author of the leading trademark treatise now identifies "cybersquatting" as a separate form of dilution, not involving blurring or tarnishment. See 3 J. THOMAS MCCARTHY, TRADEMARKS AND UNFAIR COMPETITION $\$ 24: 69.1$, at 24-117 (4th ed. 1998). 
Toeppen and Bucci are not particularly sympathetic defendants, and trademark or some other law should provide a cause of action against those who capture a domain name that clearly ought to belong to someone else in order to extort money from trademark owners. ${ }^{84}$ Still, there is something troubling about the erosion of the commercial use and use in commerce requirements. We may find that extending trademark protection to cover noncommercial uses of a mark, however compelling the instant case, sets a dangerous precedent for the law. Indeed, we need not look too far. The cybersquatter precedents are already being used by trademark owners to take domain names away from arguably legitimate users, such as people who want to register their last names as Internet domain $\mathrm{s}^{85}$ and those who build a "gripe site" to complain about a specific product or company. ${ }^{86}$

\section{What's Going on Here?}

Brown was critical of the entire concept of dilution in his 1948 article, ${ }^{87}$ and elsewhere he was critical of product configuration protection as well. ${ }^{88}$

84. It is worth noting that not all domain name disputes are of this character. In many cases, two or more legitimate claimants dispute the right to use a domain name, because both have rights to use the mark in the real world. See, e.g, Data Concepts, Inc. v. Digital Consulting, Iric., 150 F.3d 620, 622 (6th Cir. 1998) (involving the concurrent use of "DCr"); Gateway 2000, Inc. v. Gateway.com, Inc., 1997 U.S. Dist. LEXIS 2144, at *1 (E.D.N.C. 1997) (involving the concurrent use of "Gateway"); Network Solutions, Inc. v. Clue Computing, 946 F. Supp. 858, 859-60 (D. Colo. 1996) (involving concurrent use of the word "Clue"). Thus, creating a legal rule to govern domain names is far more complicated than one might imagine from the cybersquatter cases alone.

For an argument that the whole effort may be misguided because it inefficiently channels consumers into using domain names rather than other search technologies on the Internet, see Jon H. Oram, Case Note, The Costs of Confusion in Cyberspace, 107 YALE L.J. 869 (1997).

85. See, e.g., Avery Dennison Corp. v. Sumpton, 999 F. Supp. 1337, 1342 (C.D. Cal. 1998) (requiring the registrant of "avery.net" and "dennison.net" for common surnames to surrender the domain names to the Avery Dennison Corp., on a dilution theory). In cases that were not litigated to judgment, the corporation that owns the trademarks for the television characters Pokey and Gumby sought to take "pokey.org" away from a 12-year-old boy whose nickname was Pokey, and Archie Comic Publications sought to prevent a family from naming a Web site "veronica.org" after their newborn daughter. See Karen Kaplan, Archie Comics Drops Its Claim to Veronica.org, L.A. TIMES, Jan. 20, 1999, at C1. But see Giacalone v. Network Solutions, Inc., 1996 WL 887734 (N.D. Cal. 1996) (holding that Giacolone's registration of his son Ty's name as "ty.com" was noninfringing because it was not commercial use).

86. See Ohio Art Co. v. Watts, No. 98 CV 7338, slip op. at 4 (N.D. Ohio June 23, 1998) (enjoining a Web site from "denigrating" the plaintiff's product); BellSouth Corp. v. Internet Classified of Ohio, No. 1:96-CV-0769-CC, slip op. at 29-30 (N.D. Ga. Nov. 12, 1997) (enjoining the use of "bellsouthstinks.com" for gripe site because of purported confusion with BellSouth's official page); see also Amy Harmon, Web Wars: Companies Get Tough on Rogues, L.A. TMES, Nov. 12, 1996, at A1 (describing similar claims against gripe sites and whistleblowers brought by Time Warner, Kmart, Smith Barney, Gateway 2000 and Intel). But see Bally Total Fitness Holding Corp. v. Faber, 29 F. Supp. 2d 1161 (C.D. Cal. 1998) (refusing to enjoin the phrase "ballysucks" in a gripe site page).

87. Brown, supra note 1, at 1194. For modern arguments that dilution should be abolished, see Robert Klieger, Trademark Dilution: The Whittling away of the Rational Basis for Trademark Protection, 58 U. PITT. L. REV. 789, 795 (1997), and Port, supra note 57, at 447-62. See generally 
By contrast, I do not believe that either doctrine is entirely ill-conceived. Dilution laws and protection for product configurations both serve valuable purposes, purposes that find some grounding in trademark theory. Product configuration can sometimes serve a source-identifying function that is well-recognized by consumers: Think of the classic shape of the Coke bottle, for instance. And dilution-at least dilution by blurring ${ }^{89}$ - can "whittle away" the distinctive value of a famous trademark by giving the same mark several different associations. Therefore, protecting product configurations and preventing dilution in appropriate cases will lessen aggregate consumer confusion and thus encourage investment in the quality of the underlying product. ${ }^{90}$

Rather, I think the modern dilution and product configuration cases take a good idea and stretch it too far. The problem is that not every product configuration serves a source-identifying function. Indeed, the vast majority do not. Similarly, most trademarks are not sufficiently well-known that their use on unrelated products would create even an association in the minds of consumers. Rather, these legal doctrines are being used to serve

Malla Pollack, Time To Dilute the Dilution Statute and What Not To Do When Opposing Legislation, 78 J. PAT. \& TRADEMARK OFF. SOC'Y 519 (1996) (attacking the new federal dilution statute).

88. Brown was particularly concerned with preventing intellectual property owners from obtaining a general right to prevent copying by competitors. See Ralph S. Brown, Copyright and Its Upstart Cousins: Privacy, Publicity, Unfair Competition, 33 J. COPYRIGHT SOC'Y 301, 309 (1986); Ralph S. Brown, Design Protection: An Overview, 34 UCLA L. REv. 1341, 1341 (1987); Ralph S. Brown, Jr., Product Simulation: A Right or a Wrong?, 64 CoLUM. L. REv. 1216, 1227 (1964).

89. Dilution comes in two forms: dilution by blurring and dilution by tarnishment. See 15 U.S.C. $\$ 1125(\mathrm{a})(1)(\mathrm{A})$-(B) (1994). While true dilution by tamishment does sometimes occur-as when I use a famous mark on unrelated but shoddy goods, thus lowering the consumer's impression of goods with that name in general-the tarnishment rationale has also been hijacked and forced to serve an anti-parody function it was never intended to have. A notorious example is Deere \& Co. v. MTD Products, 41 F.3d 39, 44-45 (2d Cir. 1994), where the court found that a humorous use of a competitor's mark in a comparative advertisement "tamished" the mark. See also Coca-Cola Co. v. Alma-Leo U.S.A., Inc., 719 F. Supp. 725, 728 (N.D. Ill. 1989) (holding it illegal to sell powdered bubble gum in a Coca-Cola shaped bottle, not because the use of the famous bottle blurred Coke's mark, but because the association of "such a noxious substance as cocaine with plaintiff's wholesome beverage" (!) tarnished Coke's reputation). For criticism of this approach to tarnishment, see, for example, RESTATEMENT (THIRD) OF UNFAIR COMP. L. $\$$ 25(2) cmt. I (1995); 3 MCCARTHY, supra note 83, § 24:16; Denicola, supra note $\dagger$, at 1671-72; and Denicola, supra note 40 , at $195-96$.

90. Thus, there is reason to favor some dilution protection even if one agrees with Brown that the only useful function of advertising is informative, not persuasive. See Brown, supra note 1, at 1189-90. The information consumers can obtain and process is in part a function of how clear the association between mark and product remains in their minds; "clutter" therefore imposes real costs on consumers. See Burk, supra note 13, at 719; Richard A. Posner, When Is Parody Fair Use?, 21 J. LEGAL STUD. 67, 75 (1992).

Of course, trademark law may already have addressed this problem without the need for dilution, by expanding the concept of "likelihood of confusion" to assume that consumers are "gullible, careless and easily deceived" and that confusion may exist notwithstanding the dissimilarity of the products sold. See Jessica Litman, Breakfast with Batman: The Public Interest in the Advertising Age, 108 YALE L.J. 1717, 1722. 
other purposes, ones that trademark theory does not support. ${ }^{91}$ The explosion in product configuration cases in the last twenty years has a lot more to do with acquiring or extending de facto patent and copyright protection through a back door than with protecting consumers from confusion. ${ }^{92}$ And the insistence by seemingly every trademark owner that its marks must be thought famous is motivated less by genuine concerns about blurring than by a desire to 'keep up with the Cokes' and get the benefit of the same property protection that truly famous marks now receive. One can understand why trademark owners want these things, of course, but we must look to the public interest, not private interests, to decide whether trademark owners should get them. ${ }^{93}$

\section{B. Brands Take on a Life of Their Own}

A second trend in trademark law relates directly to the changing concept of what a trademark is. Rather than considering trademarks as advertisements or referents for the goods to which they are attached, courts are increasingly treating trademarks as if they were property in their own right. $^{94}$ In addition to an isolated and perhaps unique Supreme Court reference, ${ }^{95}$ this trend is evident in at least two different lines of cases.

91. Kratzke argues that dilution doctrine is misguided because it ignores consumer injury. Kratzke, supra note 12, at 285 . He has a point: Dilution statutes do not commonly require proof of consumer confusion or an appropriate substitute. Properly conceived, however, I think dilution law is protecting consumers against a real harm: the loss of the informational value of a famous trademark through crowding.

92. For criticism of this development, see, for example, Margreth Barrett, Trade Dress Protection for Product Configurations and the Federal Right To Copy, 20 HASTINGS COMM. \& ENT. L.J. 471, 476 (1998); Theodore H. Davis, Jr., Copying in the Shadow of the Constitution: The Rational Limits of Trade Dress Protection, 80 MNN. L. REV. 595 (1996); Dinwoodie, supra note 61, at 471; Melissa R. Glieberman, From Fast Cars to Fast Food: Overbroad Protection of Product Trade Dress Under Section 43(a) of the Lanham Act, 45 STAN. L. REV. 2037 (1993); cf. Tom W. Bell, Virtual Trade Dress: A Very Real Problem, 56 MD. L. REv. 384 (1997) (arguing that protecting virtual features of a digital-information product as trade dress grants patent-like protection). For an analogous argument that the federal dilution statute creates de facto copyrights, see Port, supra note 57, at 485-87.

93. Cf. Brown, supra note 1 , at 1167 (noting the public interest bound up in these decisions). For a delightful exposition of this critical fact, which seems to have gotten lost in the debate over trademark law, see Litman, supra note 90, at 1725, who notes: "There has been inexorable pressure to recognize as an axiom the principle that if something appears to have substantial value to someone, the law must and should protect it as property."

94. See Stephen L. Carter, Does It Matter Whether Intellectual Property is Property?, 68 CHI.-KENT L. REV. 715, 720-21 (1993).

95. In San Francisco Arts \& Athletics, Inc. v. United States Olympic Comm., 483 U.S. 522 (1987), the Court asserted: "[W]hen a word acquires value "as the result of organization and the expenditure of labor, skill and money' by an entity, that entity constitutionally may obtain a limited property right in the word." Id. at 532 (citing International News Serv. v. Associated Press, 248 U.S. 215, 239 (1918)). The Court in that case was interpreting a federal statute governing the word "Olympic," though, and it seems clear that that statute grants broader rights than the Lanham Act. See Amateur Sports Act § 110, 36 U.S.C. $\$ 380$ (1994). 


\section{The Merchandising Right}

First, there are a limited series of cases in which trademarks themselves have clearly become the valuable commodities. Sports team logos are obvious examples, as is the Nike "swoosh." People buy products like hats and tee-shirts because they have the logo emblazoned on them. ${ }^{96}$ This is a rather striking reversal of the normal role of trademark law. Rather than identifying the good with a particular manufacturer, and thereby guaranteeing its quality, the identifier is itself the product. There is no reason to think that the Dallas Cowboys (or their licensee, who may not be identified at all) manufacture particularly high-quality hats, or even hats of constant quality ${ }^{97}$ Rather, the logo stands alone as a thing that customers value in and of itself.

Traditional trademark theory has a tough time dealing with this use of trademarks. If the goals of trademark law are to prevent consumer confusion, or to maintain product quality standards, there is no particular reason to give trademark owners the right to control such merchandising of their marks unless consumers in fact view the mark as an identifier of source. ${ }^{98}$ Indeed, competition in the sale of Dallas Cowboys hats would arguably produce better hats at a cheaper price, and consumer welfare would be enhanced as a result. ${ }^{99}$ But at least some of the cases that have been decided do appear to give trademark owners of sports logos an

96. See Robert C. Denicola, Institutional Publicity Rights: An Analysis of the Merchandising of Famous Trade Symbols, 62 N.C. L. REv. 603, 604 (1984) (noting that items with logos sell despite their high price relative to other items of similar quality). See generally Alex Kozinski, Trademarks Unplugged, 68 N.Y.U. L. REV. 960, 961 (1993) (discussing the "growing tendency to use trademarks not just to identify products but also to enhance or adom them, even to create new commodities altogether").

97. See, e.g., MERGES ET AL., supra note 31, at 629 ("Indeed, many if not most sports logos are licensed to a broad array of products, many of differing degrees of quality. The 'high end' Red Sox cap ('just like the pros wear!') is a far different product-qua hat-than the cheap synthetic cap costing a few dollars and sold in discount stores.").

98. For an articulation and critique of possible arguments in favor of granting trademark owners control over expressive uses, see Daniel Klerman, The Expressive Function of Trademarks (Feb. 2, 1998) (working paper, on file with The Yale Law Journal).

Judge Kozinski suggests that for a certain class of goods-Veblen goods, which maintain their snob appeal precisely because only a few people can afford them-exclusive control over merchandising may help preserve the image consumers want to associate with the goods. His example involves counterfeit Rolex watches, which if they proliferate may destroy consumer expectations about what it means to wear a Rolex. See Kozinski, supra note 96, at 969-70; accord Richard S. Higgins \& Paul H. Rubin, Counterfeit Goods, 29 J.L. \& ECON. 211, 214 (1986). Even if this is a valid utilitarian rationale for trademark protection, it does not extend beyond Veblen goods to normal goods, as Judge Kozinski acknowledges.

99. See Paul J. Heald, Filling Two Gaps in the Restatement (Third) of Unfair Competition: Mixed-Use Trademarks and the Problem with Vanna, 47 S.C. L. Rev. 783, 788-89 (1996). It has been suggested that one reason consumers buy such products is because they know they are supporting the 'home team' financially. I am not sure this is a plausible explanation in the case of sports teams, and I seriously doubt it explains the purchase of Nike-logo tee-shirts. But if it did, sports teams or companies could compete by advertising the fact that money goes to support the team, whether or not they had exclusive merchandising rights. 
exclusive "merchandising" right. ${ }^{100}$ Further, there is no question that an enormous amount of licensing activity proceeds on the assumption that they have such a right. The effect of such a merchandising right is to give trademark "owners" something they have never traditionally had: the right to control the use of the mark in totally unrelated circumstances. ${ }^{101}$ Further, at least some courts have taken the merchandising right so far as to conclude that "consumer confusion" may occur where consumers are not in fact confused about the relationship between the two products, but nonetheless believe that the defendant might have needed a license to use the mark. ${ }^{102}$ This right stems not from the traditional rationales for trademark protection, but from a sense of trademarks (or sports logos, at least) as valuable things that can be owned in and of themselves. ${ }^{103}$

In these cases, trademark law is used to assert exclusive ownership rights over any commercial use of the mark in question, whether or not the

100. See, e.g., Boston Prof'l Hockey Ass'n v. Dallas Cap \& Emblem Mfg., 510 F.2d 1004, 1012 (5th Cir. 1975). The court there reasoned that since consumers identified the logo with the hockey team, the team should have a trademark right in it. This is something of a non sequitur, though. There was no evidence that the consumer connected the logo to the manufacture of the shirts, the traditional trigger for trademark protection. See also Boston Athletic Ass'n v. Sullivan, 867 F.2d 22 (1st Cir. 1989) (holding that the sponsors of the Boston Marathon could prevent the sale of unauthorized Boston Marathon tee-shirts).

On the other hand, some courts have rejected such a merchandising right. See, e.g., International Order of Job's Daughters v. Lindburg \& Co., 633 F.2d 912 (9th Cir. 1981) (permitting the use of the organization's mark on jewelry); University of Pittsburgh v. Champion Prods., 566 F. Supp. 711 (W.D. Pa. 1983) (permitting a clothier to sell products with the University of Pittsburgh insignia).

Merchandisers may also be able to use the doctrine of "post-sale confusion" to argue that even if consumers understand that they are not purchasing an authorized tee-shirt, those who see the tee-shirt being worn will themselves be confused. But it is not clear how far this doctrine extends. For an interesting discussion, see Plasticolor Molded Prods. v. Ford Motor Co., 713 F. Supp. 1329, 1339-40 (C.D. Cal. 1989).

101. See generally Peter Jaffey, Merchandising and the Law of Trade Marks, 3 INTELL. PROP. Q. 240, 240-42 (1998) (noting that trademark law does not support a general merchandising right). Of course, sports teams have the normal trademark rights to prevent the use of a confusingly similar name by another sports team. See, e.g., Indianapolis Colts, Inc. v. Metropolitan Baltimore Football Club, 34 F.3d 410 (7th Cir. 1994) (enjoining use of the name "Colts" for a football team in Baltimore, shortly after the Baltimore Colts moved to Indianapolis); cf. Harlem Wizards Entertainment Basketball, Inc. v. NBA Properties, 952 F. Supp. 1084 (D.N.J. 1997) (refusing to enjoin "Washington Wizards" as a basketball team name, because the plaintiff Harlem Wizards could not demonstrate likely confusion).

102. See Anheuser-Busch v. Balducci Publications, 28 F.3d 769, 775 (8th Cir. 1994); accord Pebble Beach Co. v. Tour 18 I Ltd., 155 F.3d 526, 544-45 (5th Cir. 1998). For criticism of this approach, see, for example, Lunney, supra note 19 (manuscript at 31, 43), who suggests that this approach is intellectually dishonest; and Tyler T. Ochoa, Dr. Seuss, The Juice and Fair Use: How the Grinch Silenced a Parody, 45 J. COPYRIGHT SOC'Y 546, 624 (1998).

103. Robert Denicola offers a moral justification for exclusive merchandising rights, based essentially on the fact that no one else has a better claim to the commercial value of the mark itself than the mark owner. See Denicola, supra note 96, at 640-41; Jerre B. Swann \& Theodore H. Davis Jr., Dilution, an Idea Whose Time Has Gone: Brand Equity as Protectable Property, the New/Old Paradigm, 1 J. INTELL. PROP. L. 219, 238 (1994). But this seems to assume the answer to the crucial question: whether anyone should have exclusive rights to the use of the mark in this context. 
use is "trademark use" or is likely to cause confusion as to the source. Merchandising rights divorce trademarks from the goods they supposedly advertise and therefore from trademark theory as well. The "Dallas Cowboys" trademark identifies a football team. The team can of course use trademark law to prevent competition by another team using the same name or even to prevent consumer confusion as to affiliation or sponsorship. But when trademark law reaches beyond that - when it precludes a haberdasher from selling a hat with the "Cowboys" logo, even when the circumstances preclude a finding of consumer confusion-it has left its theoretical foundations. The haberdasher is not using the "Cowboys" logo as a trademark; she is simply reproducing it. Consumers are not confused, at least assuming she uses an appropriate disclaimer and makes no false reference to an "official licensed NFL product." ${ }^{104}$ Nor can the trademark owner make a plausible case that this competing sale will weaken the connection between the mark and the team. True, the Cowboys might make less money than they would if trademarks were absolute property rights, and they might argue that this "discourages investment." But so what? The point of trademark law has never been to maximize profits for trademark owners at the expense of competitors and consumers. And the investment at issue in these cases is not investment in the quality of the underlying product (the team), but in merchandising the brand itself. Brown quite sensibly suggests that this ought not to be the goal of the law. ${ }^{105}$

Ironically, having accepted the merchandising rationale for certain sorts of trademarks, we may find it hard to undo. It is possible that consumers have come to expect that "Dallas Cowboys" caps are licensed by the Cowboys, not because they serve a trademark function, but simply because the law has recently required such a relationship. If this expectation exists, consumers may be confused if the law changes. ${ }^{106}$ But a limited, likelihoodof-confusion rationale for keeping a bad law intact is quite different from a theoretical justification for cementing and extending the merchandising right. There are lots of famous marks and icons for which we have not granted merchandising rights. No one controls the exclusive right to make "Statue of Liberty" tee-shirts or paperweights, for example. Even if we decide not to undo what we have done in the sports cases, there is no reason

104. In cases in which consumers are confused, of course, ordinary trademark doctrine will provide a remedy.

105. See Brown, supra note 1, at 1177-80. Others have echoed this view. See, e.g., Cohen, supra note 5, at 815; Cohen, supra note 35, at 506-14; Heald, supra note 99, at 791-92; Litman, supra note 90 , at $1729-30$.

106. Lunney derides this sort of confusion argument as circular, see Lunney, supra note 19 (manuscript at 33), and, of course, in some sense it is. But if we are committed to basing trademark doctrine on consumer reactions, we are probably stuck with those reactions even if the law itself initially helped create them. 
to take it any further, since it is hard to find any theoretical or statutory basis for the property approach to trademarks. ${ }^{107}$

Nor should we be particularly concerned that consumers seem to want to treat trademarks as things in themselves. Most sociologists would look at the premium prices paid for certain brand logos as "irrational" preferences. If the consumer really is king, however, this may not be a fair judgment. ${ }^{108}$ But it does not follow that because something is valuable it must be owned. ${ }^{109}$

\section{Licensing and Assignment of Trademarks "in Gross"}

A second way in which trademarks are increasingly being treated as property involves the sale and licensing of trademarks without the accompanying business or goodwill of the company that developed them. Unlike copyrights and patents, which have the alienability attributes of real property, ${ }^{100}$ trademarks have never been freely alienable. ${ }^{111}$ Indeed, selling a trademark without the accompanying business assets or goodwill is called "assignment in gross," and it can lead to the invalidation of the trademark. ${ }^{112}$ Unsupervised licensing of a trademark can invalidate it as well. ${ }^{113}$ The rationale for preventing free alienation of trademarks is closely tied to trademark theory. ${ }^{114}$ It is hard to see how the goals of preventing consumer confusion and encouraging investments in product quality would be furthered by allowing a company to sell the rights to a mark to another who will not make the same products. If anything, assignments in gross are vehicles for adding to consumer confusion, not reducing it. ${ }^{115}$

107. Judge Kozinski suggests that a case-by-case balancing approach is appropriate in these circumstances. See Kozinski, supra note 96, at 971.

108. For a discussion of this issue, see Malla Pollack, Your Image Is My Image, 14 CARDOZO L. REV. 1391 (1993).

109. For a particularly good elaboration on this point, see Litman, supra note 90 , at 1728-29.

110. See 17 U.S.C. § 201(d)(e) (1994); 35 U.S.C. \$ 261 (1994).

111. See Kenneth L. Port, supra note 36, at 553 ("Trademarks, on the other hand, enjoy none of the 'bundle of rights' that other forms of property enjoy.... Mark holders do not possess a property right in the mark itself, because trademarks are nothing when devoid of the goodwill they have come to represent or the product on which they are used.").

112. The Lanham Act provides that the trademark owner can assign the mark along with the accompanying goodwill. See 15 U.S.C. \& 1060 (1994). The negative implication is that it cannot be assigned otherwise. See Pepsico v. Grapette Co., 416 F.2d 285, 289-90 (8th Cir. 1969) (invalidating a trademark assigned in gross). For a discussion of the rule against assignment in gross, see 2 MCCARTHY, supra note 83 , §§ 18:1-14, at 18-4 to 18-25.

113. See, e.g., Stanfield v. Osborne Indus., 52 F.3d 867, 871-72 (10th Cir. 1995); Dawn Donut Co. v. Hart's Food Stores, 267 F.2d 358, 366 (2d Cir. 1959).

114. Indeed, the Supreme Court in American Steel Foundries v. Robertson, 269 U.S. 372 (1926), expressly traced the reasons for the rule to the fact that trademarks were only symbols of goodwill, rather than property in and of themselves. Id. at 380 .

115. See, e.g., Stephen L. Carter, The Trouble with Trademark, 99 YALE L.J. 759, 786 (1990) ("The deterioration of the prohibition on transfers in gross is a reflection of the continuing judicial misunderstanding of the theoretical underpinnings of trademark law. As a matter of theory, the 
Nonetheless, the trend in trademark law clearly seems to be toward permitting assignments in gross and "naked," or unsupervised, trademark licenses. Indeed, one could even argue that GATT TRIPs compels such a change. ${ }^{116}$ While U.S. courts have not abandoned the rule against assignments in gross, they are more willing than ever before to permit transfers with minimal associated goodwill, particularly in the context of allowing financiers to take a security interest in trademarks. ${ }^{17}$ At the very least, the historic hostility of trademark law to any licensing has abated. ${ }^{118}$

Judicial willingness to permit firms to sell trademarks as things in and of themselves is further evidence of the propertization trend that Brown abhorred in trademark law. It is also evidence of the disconnect between the law and trademark theory. Not only are assignments in gross unsupported by the traditional economic rationale for trademarks, but they do active damage to the goals of trademark law. The mental associations consumers make between trademarks and products are weakened by such transfers. ${ }^{119}$

\section{Trampling on Free Expression}

The expansive power that is increasingly being granted to trademark owners has frequently come at the expense of freedom of expression. As trademarks are transformed from rights against unfair competition to rights

prohibition on transfers in gross should be a firm one."); Kratzke, supra note 12, at 247-49 (offering an economic rationale for the rule against assignments in gross).

Landes and Posner point out that trademark owners will frequently have an incentive to maintain the quality of goods they sell, even after a transfer of trademark rights in gross. Only in "final period" cases, where a company might want to spend down its stock of goodwill, will a transfer pose risks that a buyer will deliberately sell shoddy goods. Landes \& Posner, supra note 19 , at 274-75. Whether or not a transfer is part of a final period game, however, a consumer's mental association between a trademark and a particular product will generally be weakened by assignments in gross. Indeed, Landes and Posner themselves note that an assignment in gross makes economic sense primarily when it will involve confusing a significant number of consumers. See id. at 285.

116. See Agreement on Trade-Related Aspects of Intellectual Property Rights, art. 21, Apr. 15, 1994, Marrakesh Agreement Establishing the World Trade Organization, Annex 1C, LEGAL INSTRUMENTS-RESULTS OF THE URUGUAY ROUND vol. 31 (1994), 33 I.L.M. 81 (1994).

117. See, e.g., In re Roman Cleanser Co., 802 F.2d 207, 208-09 (6th Cir. 1986); Money Store v. Harriscorp Finance, Inc., 689 F.2d 666, 676-77 (7th Cir. 1982). For general discussions of the problems of security interests in trademarks, see Alice Haemmerli, Insecurity Interests: Where Intellectual Property and Commercial Law Collide, 96 COLUM. L. REV. 1645 (1996), and Paul Heald, Resolving Priority Disputes in Intellectual Property Collateral, 1 J. INTELL. PROP. L. 135 (1993). For an argument endorsing this approach, see Allison Sell McDade, Note, Trading in Trademarks-Why the Anti-Assignment in Gross Doctrine Should Be Abolished When Trademarks Are Used as Collateral, 77 TEx. L. REV. 465 (1998).

118. See 2 MCCARTHY, supra note 83 , $\S ~ 18: 38-42$, at $18-60$ to $18-69$.

119. There is a positive economic case to be made for free alienability in general. Restraints on alienation generally interfere with the operation of the market and may prevent assets from being put to their highest and best use. While this is a powerful argument when applied to most assets, it is much weaker when applied to trademarks, since the asset is only supposed to exist in connection with particular goods made by a particular manufacturer. 
to control language, our ability to discuss, portray, comment, criticize, and make fun of companies and their products is diminishing.

There are persuasive reasons to permit political and social uses of trademarks. ${ }^{120}$ With the importance of brand image in today's economy, trademarks "form an important part of the public dialog on economic and social issues." 121 Many commentators have noted that modern expression frequently requires the use of trademarks in their role as social referents, whether or not the product itself is being discussed directly. ${ }^{122}$ As Judge Alex Kozinski has noted: "Much useful social and commercial discourse would be all but impossible if speakers were under threat of an infringement lawsuit every time they made reference to a person, company or product by using its trademark." 123

But that is exactly what appears to be going on in a variety of contexts. Trademark laws have been used to preclude artists from painting in the same style as another, ${ }^{124}$ to prevent an author from using the term "Godzilla" in the title of his book about Godzilla, ${ }^{125}$ to prevent a comic book from featuring a character known as Hell's Angel, ${ }^{126}$ to prevent a satirical political advertisement from using the "Michelob" trademark to

120. For constitutional arguments, see Denicola, supra note 40 , at 158 ; Wendy J. Gordon, $A$ Property Right in Self-Expression: Equality and Individualism in the Natural Law of Intellectual Property, 102 YALE L.J. 1533, 1537 (1993); and Mark A. Lemley \& Eugene Volokh, Freedom of Speech and Injunctions in Intellectual Property Cases, 48 DUKE L.J. 147, 171-78 (1999).

121. 5 MCCARTHY, supra note 83, § 31:146, at 31-213; see also L.L. Bean v. Drake Publishers, 811 F.2d 26, 30 (1st Cir. 1987) (" “[T]rademarks offer a particularly powerful means of conjuring up the image of their owners, and thus become an important, perhaps at times indispensable, part of the public vocabulary." (quoting Denicola, supra note 40, at 195-96)).

122. See Keith Aoki, How the World Dreams Itself To Be American: Reflections on the Relationship Between the Expanding Scope of Trademark Protection and Free Speech Norms, 3 LOY. L.A. ENT. L.J. 523, 528 (1997); Denicola, supra note 40, at 195-96; Dreyfuss, supra note 39, at 397-98; Mira Wilkins, The Neglected Intangible Asset: The Influence of the Trade Mark on the Rise of the Modern Corporation, Bus. HisT., Jan. 1992, at 66, 87-88; Steven M. Cordero, Note, Cocaine-Cola, the Velvet Elvis, and Anti-Barbie: Defending the Trademark and Publicity Rights to Cultural Icons, 8 FORDHAM INTELL. PROP. MEDIA \& ENT. L.J. 599, 601-03 (1998); Tara J. Goldsmith, Note, What's Wrong with This Picture? When the Lanham Act Clashes with Artistic Expression, 7 FORDHAM INTELL. PROP. MEDIA \& ENT. L.J. 821, 877-78 (1997). There is a significant sociological literature on the process by which consumers "recode" products and brands, imbuing them with independent social significance in a way frequently not intended by the trademark owner. For a discussion, see Michael Madow, Private Ownership of Public Image: Popular Culture and Publicity Rights, 81 CAL. L. REv. 125, 140 (1993).

123. New Kids on the Block v. News Am. Publ'g, 971 F.2d 302, 307 (9th Cir. 1992); see also Yankee Publ'g v. News Am. Publ'g, 809 F. Supp. 267, 275-76 (S.D.N.Y. 1992) (holding that the First Amendment is implicated by expressive, rather than commercial, uses of a trademark); Denicola, supra note 40, at 194-96.

124. See Romm Art Creations Ltd. v. Simcha Int'l, 786 F. Supp. 1126 (E.D.N.Y. 1992).

125. See Toho Co. v. William Morrow \& Co., 46 U.S.P.Q.2d 1801 (C.D. Cal. 1998). This decision is all the more remarkable because of the presence of disclaimers on both the front and back covers of the book.

126. See White v. Samsung Elecs. Am., 989 F.2d 1512, 1513 n.6 (9th Cir. 1993) (detailing the Hell's Angel trademark suit and the settlement). 
help make its point, ${ }^{127}$ to prevent a tractor manufacturer from making fun of its competitor's logo in an advertisement, ${ }^{128}$ to prevent a movie about a Minnesota beauty pageant from using the title "Dairy Queens," ${ }^{129}$ to prevent a political satire of the O.J. Simpson case called "The Cat NOT in the Hat!" "130 to prevent individuals from setting up web pages critical of a company or product, ${ }^{131}$ and to prevent a theme bar from calling itself "The Velvet Elvis." 132 Each of these cases involves the appropriation of a word or style, allowing the trademark owner to preclude even social discussion of the mark qua mark. Even more troubling, some of these cases seem designed precisely to prevent others from using a mark to criticize or make fun of a company. In still other cases, plaintiffs have tried without success to prevent a variety of artists, authors, political groups, news agencies, and others from using their trademarks. ${ }^{133}$ Even where these cases do not succeed, the fact that they are regularly filed and litigated to judgment may have a chilling effect on speech that happens to involve trademarks. ${ }^{134}$

Further, trademark law is encroaching upon public discourse in another way: by seeking to control not just the terms of discourse, but also the depiction of the landscape as well. Landowners claim to have trademark rights in the Rock and Roll Hall of Fame and Museum, ${ }^{135}$ the Chrysler Building, ${ }^{136}$ the façade of the New York Stock Exchange ${ }^{137}$ and numerous

127. See Anheuser-Busch v. Balducci Publications, 28 F.3d 769 (8th Cir. 1994) (rejecting a First Amendment parody argument because the parody was likely to confuse consumers). For criticism of this case, see supra note 102 and accompanying text.

128. See Deere \& Co. v. MTD Prods., 41 F.3d 39, 44-45 (2d Cir. 1994).

129. See American Dairy Queen Corp. v. New Line Prods., No. 98-CV-1923 JMR FLN, 1998 WL 915449 (D. Minn. Dec. 22, 1998).

130. Dr. Seuss Enters. v. Penguin Books USA, 109 F.3d 1394, 1397 (9th Cir. 1997). For criticism of this result, see Ochoa, supra note 102, at 589-99.

131. See Ohio Art Co. v. Watts, No. 98 CV 7338, slip op. at 4 (N.D. Ohio June 23, 1998); BellSouth Corp. v. Internet Classified of Ohio, No. 1:96-CV-0769-CC, slip op. at 29-30 (N.D. Ga. Nov. 12, 1997).

132. See Elvis Presley Enters. v. Capece, 141 F.3d 188 (5th Cir. 1998) (holding that the use of the name "The Velvet Elvis" by a nightclub was likely to confuse consumers as to sponsorship, and rejecting parody defenses).

133. See, e.g., New Kids on the Block v. News Am. Publ'g, 971 F.2d 302 (9th Cir. 1992) (allowing a newspaper to refer to the band "New Kids on the Block" in a for-profit telephone poll); Lyons Partnership v. Giannoulas, 14 F. Supp. 2d 947 (N.D. Tex. 1998) (permitting a comedy routine by the San Diego Chicken in which it beat up a Barney character); Lucasfilm Ltd. v. High Frontier, 622 F. Supp. 931 (D.D.C. 1985) (permitting the use of the term "Star Wars" to describe the Reagan Administration's Strategic Defense Initiative); Girl Scouts v. Personality Posters Mfg., 304 F. Supp. 1228 (S.D.N.Y. 1969) (refusing to enjoin printing, distribution and sale of a poster showing a pregnant girl in a Girl Scout uniform with the caption "Be Prepared").

134. See White v. Samsung Elecs. Am., 989 F.2d 1512, 1519-20 (9th Cir. 1993).

135. See Rock \& Roll Hall of Fame \& Museum v. Gentile Prods., 134 F.3d 749 (6th Cir. 1998).

136. See U.S. Trademark No. 1,126,888 (Nov. 20, 1979); David W. Dunlap, What Next? A Fee for Looking?, N.Y. TIMES, Aug. 27, 1998, at F1.

137. See Dunlap, supra note 136, at F1; SN 74-069,319, OfFICIAL GAZETTE OF THE U.S. PATENT AND TRADEMARK OFFICE, Jan. 5, 1993, at TM 217. 
other buildings in Manhattan, ${ }^{138}$ and even the shape of their golf courses. ${ }^{139}$ They have sought to use these rights not only to prevent the construction of competing architecture, but also to preclude (or get paid for) the depiction of their buildings in any form whatsoever. ${ }^{140}$ This latter power, in particular, interferes with a wide variety of noncommercial uses of these "marks."

Brown did not talk much about this use of trademarks, probably because no one in 1948 could seriously have thought the law would contemplate granting such a right. But there can be no doubt that he would have opposed this development. In these cases, trademark law is being used to suppress social, political, or artistic speech that happens to include the trademark. The defendants in these cases are not using the trademarks in a way that confuses the consuming public or destroys the trademark owner's incentives to invest in product quality. They are simply making statements that the trademark owner either does not like and wants to suppress, or for which the owner wants to collect money. Trademark theory offers no justification for this sort of suppression of speech. It is an unintended consequence of the tendency to give unfettered property rights to trademark owners.

\section{RESTORING COMMON SENSE TO TRADEMARK LAW}

If I am right that trademark owners are obtaining property rights that trademark theory cannot justify, what should be done? For the most part, I believe the courts can handle this problem, if they are vigilant in relating the protection plaintiffs seek to the principles of trademark theory and rejecting claims that are not well-founded on trademark principles. ${ }^{141} \mathrm{We}$ do not need new legal rules here; what we need is the principled and vigorous application of the old rules. Courts should ask, as Brown does, exactly what new incentives do we need trademark law to create? How are consumers hurt by the conduct at issue? And what are the interests of society at large? Brown's answer to these questions still rings true today: "[T]he only interests in trade symbols worth protecting are those against loss of sales or loss of reputation." 142

138. See Dunlap, supra note 136, at F1.

139. See Pebble Beach Co. v. Tour 18 I Ltd., 115 F.3d 526 (5th Cir. 1998).

140. See Dunlap, supra note 136, at F1.

141. See Heald, supra note 41 , at $428-29$ (arguing for particular judicial vigilance in trademark cases, where the interests of consumers are almost never represented directly by the parties).

142. Brown, supra note 1, at 1201. Brown thought this left no place for an antidilution statute in the trademark laws. I disagree. In limited circumstances, dilution can cause a loss of reputation-not immediately, but (as one court put it) as "an infection which, if allowed to spread, will inevitably destroy the advertising value of the mark." Mortellito v. Nina of Cal., Inc., $335 \mathrm{~F}$. Supp. 1288, 1296 (S.D.N.Y. 1972). 
Courts should of course protect trademarks against uses that are likely to cause confusion, and against true cases of dilution. And they should be willing to recognize that trademarks can come in many forms, including product configuration, sounds, and colors. ${ }^{143}$ But they should resist the inevitable attempts by trademark owners to expand these categories without limit. In particular, they should recognize that the Lanham Act is not a general anti-copying statute-and indeed that not all copying of a competitor's product is bad.

Eradicating the property rationale for trademarks, and restoring common sense to the Lanham Act, will be hard work. The forces arrayed in favor of propertization are powerful indeed. And it is true, as Brown points out, that "the restraining influence of the courts is largely passive." ${ }^{144}$ But the courts do have some tools available for this project. The federal dilution statute vests great discretion in the courts in deciding whether a mark is famous. To date, courts have not imposed significant limitations on parties seeking to designate their marks as famous, but they certainly could (and should) do so. ${ }^{145}$ Similarly, the distinctiveness and functionality doctrines, if broadly applied, will help distinguish those few cases in which product configurations actually serve a source-identifying function from the vast majority of products that are simply products. ${ }^{146}$ Taking the likelihood of confusion requirement, the fair use doctrine, and the doctrine of nontrademark use ${ }^{147}$ seriously will also help prevent unwarranted expansion of trademark rights in ways unforeseen by the drafters of the Lanham Act. ${ }^{145}$

143. See generally Qualitex Co. v. Jacobson Prods. Co., 514 U.S. 159 (1995) (protecting the green-gold color of press pads used in drycleaning as a trademark and recognizing the wide range of protectable marks).

144. Brown, supra note 1 , at 1206.

145. McCarthy wisely suggests that while dilution is a legitimate cause of action in some cases, "it is up to the judiciary to apply such potent laws with care and common sense lest they damage the competitive system they are designed to enhance." 3 MCCARTHY, supra note 83, $\S 24: 114$, at $24-209$. At the very least, courts should heed the congressional statement that "famous marks ordinarily are used on a nationwide basis." H.R. REP. No. 104-374, at 3 (1995).

For recent opinions that cabin the reach of the dilution statute somewhat, see I.P. Lund Trading v. Kohler Co., 163 F.3d 27, 42 (1st Cir. 1998), which holds that fame must involve more than simply having a strong, distinctive mark; and Jet Inc. v. Sewage Aeration Sys., 165 F.3d 419, 425 (6th Cir. 1999), which holds that a dilution plaintiff must show a greater degree of similarity between the marks than would be necessary in an ordinary trademark case.

146. See RESTATEMENT (THIRD) OF UNFAIR COMP. $\$ 16 \mathrm{cmt}$ b (1993) ("Rigorous application of the requirements of distinctiveness and nonfunctionality is necessary in order to avoid undermining the carefully circumscribed statutory regimes for the protection of useful and ornamental designs under federal patent and copyright law."). For a detailed exposition of how to apply these doctrines in product configuration cases, see Oddi, supra note 61, at 137-60.

147. The latter two doctrines, properly applied, permit defendants to use words in their descriptive sense, rather than as a trademark, and to use trademarks to refer accurately to the trademark owner's product. See MERGES ET AL., supra note 31, at 574 (fair use), 711-14 (nontrademark use).

148. Alternatively, courts could turn the focus away from likelihood of confusion and towards the speech significance of the mark, at least in cases that involve expressive uses of trademarks. For one proposal along these lines, see Dreyfuss, supra note 39, at 418-19. 
Finally, the First Amendment stands (or should stand) as a bulwark against the increasingly common effort to use trademark law to suppress speech. ${ }^{149}$

\section{CONCLUSION}

The world has changed dramatically since Ralph Brown wrote his 1948 article. Trademark law and trademark economics have both made significant strides in the last fifty years, but unfortunately, they do not seem to be marching in lockstep. Rather, the law has broken stride with economic thinking in dangerous ways. I do not think Brown would approve of the ways trademark law has changed in the last fifty years, but perhaps he would recognize them. He wrote: "In an acquisitive society, the drive for monopoly advantage is a very powerful pressure. Unchecked, it would no doubt patent the wheel, copyright the alphabet, and register the sun and moon as exclusive trade-marks." 150

We seem to be moving down that road. Unless we are careful, we may end up in a world in which every thing, every idea, and every word is owned. And we will all be the poorer for it.

149. A detailed elaboration of the interaction between the First Amendment and the trademark laws is beyond the scope of this Essay. For one specific argument along these lines, see Lemley \& Volokh, supra note 120, at 147. For a more general argument, see Cordero, supra note 122, at 608-28; and Denicola, supra note 40, at 158.

150. Brown, supra note 1 , at 1206. 
